\title{
Anxiety level in pregnant women in the first year of COVID-19 pandemic
}

\author{
Esra Tamburaci* \\ Department of Obstetrics and Gynecology, Antalya Training and Research Hospital Gynecology and Obstetrics Clinic, \\ Antalya, Turkey
}

Received: 27 July 2021

Accepted: 03 September 2021

\section{*Correspondence:}

Dr. Esra Tamburaci,

E-mail: dresratamburaci@gmail.com

Copyright: $\odot$ the author(s), publisher and licensee Medip Academy. This is an open-access article distributed under the terms of the Creative Commons Attribution Non-Commercial License, which permits unrestricted non-commercial use, distribution, and reproduction in any medium, provided the original work is properly cited.

\section{ABSTRACT}

Background: The study was aimed to determine the effect of the ongoing infection on the anxiety level of pregnant women during the first year of the COVID-19 pandemic.

Methods: In this study, a structured questionnaire and the Beck anxiety inventory were administered to pregnant women who volunteered to participate in the research among the ones who applied to the outpatient clinic for routine prenatal care from January 2021-March 2021.

Results: The study featured 200 pregnant women with a mean age of $28.3 \pm 6.8$ years and a range of $18-45$ years. The patients were divided into four groups according to their Beck score as minimal (38.5\%), mild (42\%), moderate (15.5\%), and severe (4\%) levels of anxiety. Women with moderate and severe levels of anxiety were observed to have higher rates of fear of getting infected with COVID-19, fear of infecting the baby, fear of death due to COVID-19, fear of losing her relative due to COVID-19, fear of losing her baby due to COVID-19, and fear of quarantine ( $\mathrm{p}<0.001$ ). Factors that independently affected the level of anxiety in pregnant women were examined by multivariate linear regression analysis. It was found that increasing age $(\beta=0.246 ; p<0.001)$, fear of getting infected with COVID-19 $(\beta=0.375 ; p<0.001)$, fear of death due to COVID-19 $(\beta=0.105 ; p=0.044)$ and fear of losing her baby due to COVID-19 $(\beta=0.205 ; p<0.001)$ positively associated with anxiety levels.

Conclusions: Because of the detrimental impact on both the mother and the infant, perinatal mental wellbeing is a major public health concern. Thus, aside from the follow-up of pregnant women by a multidisciplinary team of perinatology, neonatology, and intensive care specialists, it is essential to provide psychosocial support during the pandemic.

Keywords: COVID-19 pandemic, Pregnancy, Beck anxiety score, Anxiety level

\section{INTRODUCTION}

COVID-19 infection, which occurred in Wuhan, China, in December 2019, caused by the coronavirus family severe acute respiratory syndrome corona virus-2 (SARS-CoV2), was declared a pandemic by the World Health Organization in March 2020. This epidemic has a mortality rate of $2.3 \%$ higher than the flu and is more infectious than extreme acute respiratory syndrome (SARS). ${ }^{1,2}$
This infection, which has serious morbidity and mortality rates, has also led to significant effects on mental health. Similar to Middle East respiratory syndrome (MERS) infection, post-traumatic stress disorder, obsession disorders, anxiety, and depressive disorders are widely observed in this infection. ${ }^{3}$ Studies undertaken during recent similar outbreaks (SARS and MERS) have revealed that pregnant women are more likely to be psychologically affected by such cases. ${ }^{4}$ 
Though hormonal variations in pregnant women are already a source of concern, increases in their anxiety levels were observed throughout pregnancy due to fears of infecting the baby during the pandemic, pregnancy-related complications, the fear of losing relatives, and pandemicrelated restrictions (lockdown, lack of healthcare and accessibility). ${ }^{5}$

COVID-19 infection, which is declared as a pandemic, caused a significant increase in stress and anxiety levels as well as increased morbidity and mortality rates. Normally, the concern of something going wrong, which is caused by hormonal changes during pregnancy, has been observed to increase with the pandemic, raising anxiety levels in pregnant women. Our aim in this study is to determine the effect of COVID-19 infection, which is a global health problem, on the anxiety level of pregnant women and to discuss this in the light of the literature.

\section{METHODS}

In this study, we aimed to determine the level of anxiety about COVID-19 in pregnant women who visited our clinic for routine prenatal care. 200 voluntary pregnant women aged 18 to 45 who applied to the outpatient clinic for routine control between January 2021 and March 2021 were informed about the study, their consents were obtained, and two questionnaires were filled out. The first questionnaire asked about the number of pregnancies, the week of pregnancy, educational status, work status of the spouse and herself, family structure, domestic violence, fear of getting infected with COVID-19, fear of infecting the baby, fear of losing relatives, and included the demographic data of all pregnant women. At the same time, the Beck anxiety scale, consisting of 21 items, was completed as a second questionnaire, and the frequency of anxiety symptoms in the past month was rated using a 4point Likert scale ranging from 0 (none) to 3 (severe). ${ }^{6}$ The Beck anxiety inventory has a cumulative score range of 0 to 63 , with higher scores representing a higher level of anxiety. Pregnant women between the ages of 18-45 who applied to the outpatient clinic for prenatal care and agreed to participate in the study voluntarily were included in our study. Pregnant women applied for emergency obstetric reasons and those with a diagnosed psychiatric illness were excluded from the study. The approval of the ethics committee of the Antalya Training and Research Hospital Ethics Committee (dated 01.04.2021 and decision number 4/2) was received for this study and informed consent was obtained from each participant before starting the study. In addition, the Ministry of Health granted approval for studies on COVID-19 that had been requested.

Cumulative scores of Beck anxiety inventory: 0-7 points $=$ minimal level of anxiety, $8-15$ points $=$ mild level of anxiety, 16-25 points=moderate level of anxiety, and 2663 points $=$ severe level of anxiety

Fear of death due to COVID-19, fear of losing a relative due to COVID-19, fear of the possibility of not having her family at birth, fear of the possibility of a forced caesarean delivery, fear of the possibility of infecting the baby, and fear of that the disease may be more severe in pregnant women and newborns, all triggered by the anxiety level caused by COVID-19, were examined in our study.

\section{Statistical analysis}

The descriptive findings were presented with mean \pm standard deviation (SD) or median (min-max) for the numerical variables, and with frequency and percentage for the categorical variables. Pearson Chisquare test and Fisher's exact test were performed for comparison of categorical variables. The normality assumptions were controlled by the Shapiro-Wilk test. Kruskal Wallis test was used for comparison of the numerical variables according to anxiety levels and Bonferroni-Dunn test was used as a post hoc test for significant cases. Spearman correlation test was used to examine the relationship between Beck anxiety and the other numerical variables. Multiple linear regression analysis was performed to determine independent risk factors associated with the anxiety levels of patients. Statistical analysis was made using IBM statistical package for the social sciences (SPSS) statistics for Windows, version 23.0 (IBM Corp., Armonk, NY). Twosided $\mathrm{p}$ values $<0.05$ were considered statistically significant.

\section{RESULTS}

The study featured 200 pregnant women with a mean age of $28.3 \pm 6.8$ years and a range of $18-45$ years. The patients were divided into four groups according to their Beck score as minimal (38.5\%), mild (42\%), moderate (15.5\%), and severe $(4 \%)$ levels of anxiety. While women with severe anxiety had higher age values, the difference was not considered significant $(\mathrm{p}=0.098)$. The distribution of the following variables was shown to be statistically similar based on women's anxiety levels: age groups $(\mathrm{p}=0.245)$, body mass index (BMI) $(\mathrm{p}=0.366)$, marital status $(p=0.535)$, migration status $(p=0.778)$, family relationship $(\mathrm{p}=0.173)$, spouse's career status $(\mathrm{p}=0.219)$, and presence of domestic violence $(\mathrm{p}=0.170)$. The rate of being a high school graduate was higher in those with moderate and severe levels of anxiety $(\mathrm{p}<0.001)$.

In pregnant women with a mild level of anxiety the rate of having a bad family relationship was found to be higher $(p=0.017)$. The rate of being employed was higher in women with moderate and severe anxiety levels $(\mathrm{p}<0.001)$. The rate of low-income patients was higher in the minimal level of anxiety group and the proportion of high-income patients was higher in the severe level of anxiety group $(\mathrm{p}=0.001)$ (Table 1$)$.

Based on the anxiety levels of women, no statistically significant difference determined in terms of gravity $(\mathrm{p}=0.114)$, parity $(\mathrm{p}=0.336)$, having given birth in the past $(\mathrm{p}=0.563)$, unintended pregnancy $(\mathrm{p}=0.084)$, pregnancy 
trimester $(\mathrm{p}=0.110)$, having regular visits for control $(\mathrm{p}=0.122)$, having pregnancy complications $(\mathrm{p}=0.074)$ and diabetes $(\mathrm{p}=0.242)$, hypertension $(\mathrm{p}=0.717)$, and having a risk of miscarriage $(p=0.340)$. Women with moderate to severe anxiety levels had a higher proportion of patients who had a previous caesarean delivery, which was found to be statistically significant $(\mathrm{p}=0.043)$ (Table 2).

In pregnant women with moderate and severe levels of anxiety, the rate of having the fear of getting infected with COVID-19, fear of infecting the baby, fear of death due to COVID-19, fear of losing a relative due to COVID-19, fear of losing her baby due to COVID-19, and fear of quarantine was observed to be higher and a statistically significant difference was detected in all groups when this situation was compared with the group with minimal or mild levels of anxiety $(\mathrm{p}<0.001)$ (Table 3$)$.
The Beck anxiety score was found to have a poor positive correlation with age $(\mathrm{r}=0.224, \mathrm{p}=0.001)$, weight $(\mathrm{r}=0.200$, $\mathrm{p}=0.005)$, and income level $(\mathrm{r}=0.339, \mathrm{p}<0.001)$, and it was found to have a very weak positive correlation with height $(\mathrm{r}=0.170, \mathrm{p}=0.016)$, BMI $(\mathrm{r}=0.150, \mathrm{p}=0.034)$, education level $(\mathrm{r}=0.187, \mathrm{p}=0.008)$, and gravity $(\mathrm{r}=0.166, \mathrm{p}=0.019)$ (Table 4).

Factors independently affected the level of anxiety in pregnant women were examined by multivariate linear regression analysis. It was found that increasing age $(\beta=0.246 ; p<0.001)$, fear of getting infected with COVID$19(\beta=0.375 ; p<0.001)$, fear of death due to COVID-19 $(\beta=0.105 ; p=0.044)$ and fear of losing her baby due to COVID-19 $(\beta=0.205 ; p<0.001)$ positively associated with anxiety levels (Table 5).

Table 1: Demographic data of pregnant women according to their anxiety levels.

\begin{tabular}{|c|c|c|c|c|c|}
\hline Variables & $\begin{array}{l}\text { Normal } \\
\text { (0-7 point) }\end{array}$ & $\begin{array}{l}\text { Mild } \\
\text { (8-15 point) }\end{array}$ & $\begin{array}{l}\text { Moderate } \\
\text { (16-25 point) }\end{array}$ & $\begin{array}{l}\text { Severe } \\
\text { (26-63 point) }\end{array}$ & $P$ value \\
\hline No. of patients (\%) & $77(38.5)$ & $84(42)$ & $31(15.5)$ & $8(4)$ & - \\
\hline Age (years) & $25(18-44)$ & $28(20-45)$ & $28(20-44)$ & $32(22-44)$ & 0.098 \\
\hline 18-25 & $41(53.2)$ & $33(39.3)$ & $11(35.5)$ & $2(25)$ & 0.245 \\
\hline 26-34 & $21(27.3)$ & $32(38.1)$ & $15(48.4)$ & $3(37.5)$ & \\
\hline 35 and above & $15(19.5)$ & $19(22.6)$ & $5(16.1)$ & $3(37.5)$ & \\
\hline Height (cm) & $160(150-175)$ & $160(150-170)$ & $165(152-170)$ & $160(150-165)$ & 0.158 \\
\hline Weight (kg) & $60(50-80)$ & $65(45-85)$ & $65(55-80)$ & $65(52-75)$ & 0.155 \\
\hline BMI $\left(\mathrm{kg} / \mathrm{m}^{2}\right)$ & $23.4(19.5-33.3)$ & $25(19.5-33.3)$ & $24.6(20.2-33.3)$ & $25.2(20.2-29.3)$ & 0.366 \\
\hline \multicolumn{6}{|l|}{ Marital status } \\
\hline Married & $70(90.9)$ & $73(86.9)$ & $27(87.1)$ & $7(87.5)$ & 0.535 \\
\hline Single & $6(7.8)$ & $7(8.3)$ & $2(6.5)$ & $0(0)$ & \\
\hline In a relation & $1(1.3)$ & $4(4.8)$ & $2(6.5)$ & $1(12.5)$ & \\
\hline \multicolumn{6}{|l|}{ Education } \\
\hline Illiterate & $57(74)$ & $56(66.7)$ & $15(48.4)$ & $5(62.5)$ & $<0.001$ \\
\hline Primary & $19(24.7)$ & $24(28.6)$ & $8(25.8)$ & $0(0)$ & \\
\hline High school & $1(1.3)$ & $4(4.8)$ & $8(25.8)$ & $3(37.5)$ & \\
\hline \multicolumn{6}{|l|}{ Immigration } \\
\hline No & $67(87)$ & $70(83.3)$ & $27(87.1)$ & $8(100)$ & 0.778 \\
\hline Yes & $10(13)$ & $14(16.7)$ & $4(12.9)$ & $0(0)$ & \\
\hline \multicolumn{6}{|l|}{ Family relation } \\
\hline Good & $73(94.8)$ & $67(79.8)$ & $29(93.5)$ & $8(100)$ & 0.017 \\
\hline Bad & $4(5.2)$ & $17(20.2)$ & $2(6.5)$ & $0(0)$ & \\
\hline \multicolumn{6}{|l|}{ Family type } \\
\hline Nuclear family & $61(79.2)$ & $54(64.3)$ & $24(77.4)$ & $6(75)$ & 0.173 \\
\hline Extended family & $16(20.8)$ & $30(35.7)$ & $7(22.6)$ & $2(25)$ & \\
\hline \multicolumn{6}{|l|}{ Occupation } \\
\hline Housewife & $71(92.2)$ & $70(83.3)$ & $16(51.6)$ & $4(50)$ & $<0.001$ \\
\hline Employed & $6(7.8)$ & $14(16.7)$ & $15(48.4)$ & $4(50)$ & \\
\hline \multicolumn{6}{|l|}{ Husband occupation } \\
\hline Unemployed & $14(18.2)$ & $19(22.6)$ & $3(9.7)$ & $0(0)$ & 0.219 \\
\hline Employed & $63(81.8)$ & $65(77.4)$ & $28(90.3)$ & $8(100)$ & \\
\hline \multicolumn{6}{|l|}{ Income } \\
\hline Low & $50(64.9)$ & $41(48.8)$ & $10(32.3)$ & $2(25)$ & 0.001 \\
\hline Middle & $23(29.9)$ & $27(32.1)$ & $10(32.3)$ & $2(25)$ & \\
\hline High & $4(5.2)$ & $16(19)$ & $11(35.5)$ & $4(50)$ & \\
\hline
\end{tabular}

Continued 


\begin{tabular}{|llllll|}
\hline Variables & $\begin{array}{l}\text { Normal } \\
(\mathbf{0 - 7} \text { point })\end{array}$ & $\begin{array}{l}\text { Mild } \\
(\mathbf{8}-\mathbf{1 5} \text { point })\end{array}$ & $\begin{array}{l}\text { Moderate } \\
(\mathbf{1 6 - 2 5} \text { point })\end{array}$ & $\begin{array}{l}\text { Severe } \\
(\mathbf{2 6 - 6 3} \text { point })\end{array}$ & \multicolumn{1}{c|}{ P value } \\
\hline Domestic violence & & & $27(87.1)$ & $8(100)$ & 0.170 \\
\hline No & $70(90.9)$ & $67(79.8)$ & $4(12.9)$ & $0(0)$ & \\
\hline Psychological & $7(9.1)$ & $17(20.2)$ & & \\
\hline
\end{tabular}

Data are expressed as median (range) or n (\%); Kruskal-Wallis test with post-hoc Bonferroni-Dunn test, Pearson Chi-square test, Fisher's exact test

Table 2: Pregnancy-related data of pregnant women according to their anxiety levels.

\begin{tabular}{|c|c|c|c|c|c|}
\hline Variables & $\begin{array}{l}\text { Normal } \\
\text { (0-7 point) }\end{array}$ & $\begin{array}{l}\text { Mild } \\
\text { (8-15 point) }\end{array}$ & $\begin{array}{l}\text { Moderate } \\
\text { (16-25 point) }\end{array}$ & $\begin{array}{l}\text { Severe } \\
(26-63 \text { point })\end{array}$ & P value \\
\hline Gravida & $2(1-5)$ & $2(1-6)$ & $2(1-6)$ & $2(1-3)$ & 0.114 \\
\hline Parity & $1(0-4)$ & $1(0-4)$ & $1(0-5)$ & $1(0-2)$ & 0.336 \\
\hline \multicolumn{6}{|l|}{ Previous birth } \\
\hline No & $27(35.1)$ & $21(25)$ & $9(29)$ & $2(25)$ & 0.563 \\
\hline Yes & $50(64.9)$ & $63(75)$ & $22(71)$ & $6(75)$ & \\
\hline \multicolumn{6}{|c|}{ Previous birth type (n:141) } \\
\hline ND & $39(78)$ & $48(76.2)$ & $11(50)$ & $3(50)$ & 0.043 \\
\hline $\mathrm{C} / \mathrm{S}$ & $11(22)$ & $15(23.8)$ & $11(50)$ & $3(50)$ & \\
\hline \multicolumn{6}{|l|}{ Is the desired pregnancy? } \\
\hline No & $9(11.7)$ & $21(25)$ & $6(19.4)$ & $0(0)$ & 0.084 \\
\hline Yes & $68(88.3)$ & $63(75)$ & $25(80.6)$ & $8(100)$ & \\
\hline \multicolumn{6}{|l|}{ Trimester } \\
\hline 1 & $44(57.1)$ & $34(40.5)$ & $18(58.1)$ & $3(37.5)$ & 0.110 \\
\hline 2 & $20(26)$ & $22(26.2)$ & $9(29)$ & $2(25)$ & \\
\hline 3 & $13(16.9)$ & $28(33.3)$ & $4(12.9)$ & $3(37.5)$ & \\
\hline \multicolumn{6}{|l|}{ Pregnancy controls } \\
\hline Regular & $65(84.4)$ & $60(71.4)$ & $21(67.7)$ & $5(62.5)$ & 0.122 \\
\hline Not regular & $12(15.6)$ & $24(28.6)$ & $10(32.3)$ & $3(37.5)$ & \\
\hline Pregnancy complication & $12(15.6)$ & $26(31)$ & $11(35.5)$ & $2(25)$ & 0.074 \\
\hline DM & $2(2.6)$ & $8(9.5)$ & $3(9.7)$ & $0(0)$ & 0.242 \\
\hline HT & $5(6.5)$ & $8(9.5)$ & $3(9.7)$ & $1(12.5)$ & 0.717 \\
\hline Threat of miscarriage & $5(6.5)$ & $10(11.9)$ & $5(16.1)$ & $1(12.5)$ & 0.340 \\
\hline
\end{tabular}

Data are expressed as median (range) or $\mathrm{n}(\%)$. Kruskal-Wallis test with post-hoc Bonferroni-Dunn test, Pearson Chi-square test, Fisher's exact test

Table 3: COVID-19 related data of pregnant women according to their anxiety levels.

\begin{tabular}{|c|c|c|c|c|c|}
\hline Variables & $\begin{array}{l}\text { Normal } \\
\text { (0-7 point) }\end{array}$ & $\begin{array}{l}\text { Mild } \\
\text { (8-15 point) }\end{array}$ & $\begin{array}{l}\text { Moderate } \\
\text { (16-25 point) }\end{array}$ & $\begin{array}{l}\text { Severe } \\
\text { (26-63 point) }\end{array}$ & P value \\
\hline \multicolumn{6}{|c|}{ Fear of COVID } \\
\hline No & $76(98.7)$ & $64(76.2)$ & $3(9.7)$ & $0(0)$ & $<0.001$ \\
\hline Yes & $1(1.3)$ & $20(23.8)$ & $28(90.3)$ & $8(100)$ & \\
\hline \multicolumn{6}{|c|}{ Fear of infecting the baby } \\
\hline No & $76(98.7)$ & $64(76.2)$ & $3(9.7)$ & $0(0)$ & $<0.001$ \\
\hline Yes & $1(1.3)$ & $20(23.8)$ & $28(90.3)$ & $8(100)$ & \\
\hline \multicolumn{6}{|c|}{ The fear of death } \\
\hline No & $77(100)$ & $80(95.2)$ & $21(67.7)$ & $3(37.5)$ & $<0.001$ \\
\hline Yes & $0(0)$ & $4(4.8)$ & $10(32.3)$ & $5(62.5)$ & \\
\hline \multicolumn{6}{|c|}{ Fear of loss of close relatives } \\
\hline No & $76(98.7)$ & $77(91.7)$ & $22(71)$ & $3(37.5)$ & $<0.001$ \\
\hline Yes & $1(1.3)$ & $7(8.3)$ & $9(29)$ & $5(62.5)$ & \\
\hline \multicolumn{6}{|c|}{ Fear of infant loss } \\
\hline No & $73(94.8)$ & $74(88.1)$ & $10(32.3)$ & $0(0)$ & $<0.001$ \\
\hline Yes & $4(5.2)$ & $10(11.9)$ & $21(67.7)$ & $8(100)$ & \\
\hline
\end{tabular}




\begin{tabular}{|llllll|}
\hline Variables & $\begin{array}{l}\text { Normal } \\
(\mathbf{0}-7 \text { point })\end{array}$ & $\begin{array}{l}\text { Mild } \\
(\mathbf{8}-\mathbf{1 5} \text { point })\end{array}$ & $\begin{array}{l}\text { Moderate } \\
(\mathbf{1 6}-\mathbf{2 5} \text { point })\end{array}$ & $\begin{array}{l}\text { Severe } \\
(\mathbf{2 6}-\mathbf{6 3} \text { point })\end{array}$ & P value \\
\hline No & $76(98.7)$ & $76(90.5)$ & $21(67.7)$ & $3(37.5)$ & $<0.001$ \\
\hline Yes & $1(1.3)$ & $8(9.5)$ & $10(32.3)$ & $5(62.5)$ & \\
\hline
\end{tabular}

Data are expressed as n (\%). Pearson chi-square test, Fisher's exact test

Table 4: Correlation of Beck anxiety score with the other variables.

\begin{tabular}{|lll|}
\hline Variables & Beck anxiety score & p \\
\hline Age & r & 0.001 \\
\hline Height & 0.224 & 0.016 \\
\hline Weight & 0.170 & 0.005 \\
\hline BMI & 0.200 & 0.034 \\
\hline Education & 0.150 & 0.008 \\
\hline Income & 0.187 & $<0.001$ \\
\hline Gravida & 0.339 & 0.019 \\
\hline Parity & 0.166 & 0.071 \\
\hline
\end{tabular}

Spearman correlation test

Table 5: Independent factors associated with anxiety levels of pregnant women.

\begin{tabular}{|c|c|c|c|c|c|c|c|c|}
\hline \multirow{2}{*}{$\begin{array}{l}\text { Variables } \\
\text { Model }\end{array}$} & \multicolumn{6}{|c|}{ BECK anxiety score } & \multicolumn{2}{|c|}{$\begin{array}{l}95 \% \text { confidence } \\
\text { interval }\end{array}$} \\
\hline & B & SE & $\boldsymbol{\beta}$ & $\mathbf{t}$ & Sig. & VIF & Lower & Upper \\
\hline Constant & -9.849 & 1.502 & & -6.559 & $<0.001$ & & -12.811 & -6.887 \\
\hline Age & 0.187 & 0.047 & 0.246 & 4.005 & $<0.001$ & 2.517 & 0.095 & 0.279 \\
\hline Education & 0.005 & 0.407 & 0.001 & 0.013 & 0.990 & 1.685 & -0.797 & 0.808 \\
\hline Bad family relation & 0.055 & 0.69 & 0.003 & 0.079 & 0.937 & 1.226 & -1.307 & 1.416 \\
\hline Occupation (employed) & 0.994 & 0.689 & 0.077 & 1.442 & 0.151 & 1.886 & -0.366 & 2.354 \\
\hline Income & 0.618 & 0.345 & 0.091 & 1.79 & 0.075 & 1.732 & -0.063 & 1.299 \\
\hline Gravite & -0.609 & 0.322 & -0.126 & -1.894 & 0.060 & 2.965 & -1.243 & 0.025 \\
\hline Unwanted pregnancy & -0.056 & 0.619 & -0.004 & -0.09 & 0.928 & 1.430 & -1.277 & 1.165 \\
\hline $\begin{array}{l}\text { Fear of getting infected with } \\
\text { COVID-19 }\end{array}$ & 4.268 & 1.058 & 0.375 & 4.036 & $<0.001$ & 5.762 & 2.182 & 6.354 \\
\hline $\begin{array}{l}\text { Fear of the baby infected } \\
\text { with COVID-19 }\end{array}$ & 1.333 & 1.126 & 0.117 & 1.183 & 0.238 & 6.538 & -0.890 & 3.555 \\
\hline $\begin{array}{l}\text { Fear of death due to } \\
\text { COVID-19 }\end{array}$ & 1.839 & 0.908 & 0.105 & 2.026 & 0.044 & 1.791 & 0.048 & 3.630 \\
\hline $\begin{array}{l}\text { Fear of losing family } \\
\text { member due to COVID-19 }\end{array}$ & 0.806 & 1.648 & 0.049 & 0.489 & 0.625 & 6.725 & -2.446 & 4.058 \\
\hline $\begin{array}{l}\text { Fear of losing her baby due } \\
\text { to COVID-19 }\end{array}$ & 2.561 & 0.689 & 0.205 & 3.715 & $<0.001$ & 2.027 & 1.201 & 3.920 \\
\hline Fear of quarantine & 1.663 & 1.502 & 0.105 & 1.107 & 0.270 & 6.026 & -1.301 & 4.626 \\
\hline
\end{tabular}

$\mathrm{R}=0.849, \mathrm{R} 2=0.721, \mathrm{p}<0.001$

\section{DISCUSSION}

Numerous studies on catastrophic disasters indicate that stress associated with events such as pandemics, earthquakes, and famine may be related to both acute and long-term mental and physical health issues in both the mother and the baby. Anxiety disorder in pregnancy was reported to have a prevalence of $15.2 \%$ in a meta-analysis conducted in 2017, and anxiety symptoms had that of $22.9 \% .^{7}$ The patients were divided into four groups according to their Beck score as minimal (38.5\%), mild (42\%), moderate $(15.5 \%)$, and severe (4\%) levels of anxiety considering the general results of our study. Even though women with severe anxiety had higher age values, the difference was not considered significant $(\mathrm{p}=0.098)$. Women with moderate and severe levels of anxiety were observed to have higher rates of fear of getting infected with COVID-19, fear of infecting the baby, fear of death due to COVID-19, fear of losing her relative due to COVID-19, fear of losing her baby due to COVID-19, and fear of quarantine and these were regarded as independent risk factors $(\mathrm{p}<0.001)$. Advanced age, fear of getting infected with COVID-19, fear of death due to COVID-19, and fear of losing her baby due to COVID-19 were all 
found to be statistically significantly associated with anxiety levels and to be independent risk factors.

Many studies have been undertaken since the onset of the COVID-19 pandemic to analyse the effect of the epidemic on societal and pregnancy psychological outcomes. Higher levels of depression and anxiety in women indicated that the psychiatric impact of the COVID-19 pandemic could be greater on women, according to a study by Ozdin et al which involved 343 participants in the early stages of the pandemic. ${ }^{8}$ One of the known medical facts is that anxiety disorders and depressive disorders are more common in women. $^{9}$

Similarly, in the study conducted by Wang et al in which 600 participants were included in the People's Republic of China during the pandemic process, it was reported that the anxiety rate in women was 3.01 times higher than it was in men. Women who were pregnant during the COVID-19 pandemic are believed to have been especially affected, as women appear to show more anxiety and depression symptoms than men during disease outbreaks. ${ }^{10}$

Fear of infection and increased stress due to increased social and health responsibilities during the COVID-19 pandemic may lead to conditions such as weight gain and increased obesity due to changes in diet, muscle-joint pain, and insulin resistance. The increased duration of stay at home for family members contributes to an improvement in the activities demanded of pregnant women, such as cleaning, cooking, shopping, and ensuring the requisite hygiene against the infection, which adds to their workload. Furthermore, as seen in our research, the rise in the gestational week, the approaching birth, being contaminated, the fear of infecting the infant, the lack of proven care, and the pandemic-induced curfew all contribute to this situation.

Domestic violence is predicted to rise as a result of the pandemic's negative impacts on families' economic and psychological well-being. ${ }^{11}$ Many factors due to the pandemic process, such as an increase in the length of time spent at home, social alienation, economic difficulties as a result of workers needing to leave their jobs, and fear of getting the virus, are said to contribute to an increase in and long-term psychological problems in individuals, such as depression and anxiety disorders. ${ }^{12}$ It was stated that the duration of the quarantine period was an independent risk factor for anxiety during birth, in a study undertaken to assess anxiety symptoms in pregnant women living under quarantine conditions in Greece during the COVID-19 pandemic. ${ }^{13}$

In another study, it is stated that the measures taken to reduce the spread of the virus during the pandemic may have psychological effects that may be harmful to mental health. For instance, social distancing is known to be the key strategy to slow down the spread of the COVID-19 outbreak. However, it has been noted that attachment to others is an instinctive necessity for people all over the world and that this social bond helps us cope with stress and retain our resilience in all of life's adverse circumstances that affect our lives. ${ }^{14}$

It was stated that patients of advanced age, minority ethnicity, being overweight/obese, and comorbid conditions were more susceptible to infection and had a greater risk of morbidity and mortality, in a populationbased national prospective cohort study involving pregnant women hospitalized for COVID-19 infection in the United Kingdom. ${ }^{15}$

During the current COVID-19 outbreak, it has been suggested that fear of infection in pregnant patients could trigger psychological and mental disorders and associated suicidal thoughts and disturbance of the mother-baby bond during and after birth, which may lead to more serious issues in the future. ${ }^{16}$ It was observed that the anxiety levels of pregnant patients increased due to the infection and related complications in our study due to factors such as high level of education, working pregnant cases, high income and good family relationship, advanced age, obesity, increased gravida, length of the operative delivery process such as caesarean delivery.

Individuals who are pregnant for the first time may have a greater fear of giving birth, anxiety about the baby's health, and increased anxiety as a result of the physical changes they are going through. ${ }^{17}$ As a matter of fact, primigravida pregnant women had higher levels of anxiety than multigravida pregnant women in our study. Clinically elevated anxiety symptoms were observed in $56.6 \%$ of the participants in Lebel et al.'s study, which included 1,987 participants and evaluated the increased anxiety symptoms in pregnant individuals during the COVID-19 outbreak in Canada. In this study, anxiety symptoms due to pregnancy were found higher in nulliparous individuals when anxiety symptoms were compared with parity $(\mathrm{p}<0.0001)$. However, when the anxiety findings were compared with the parity, they stated that there was no difference. ${ }^{18}$ When evaluated in terms of anxiety in our study, increased anxiety was found in multigravida pregnant women. As previously mentioned, it is believed that there might be a rise due to pregnancy-related anxiety, such as fear of birth, maternal wellbeing, baby's health, re-parenting, financial, and social competence.

It is thought that the pandemic increases the anxiety level of pregnant women. Potential sources of maternal stress have been identified as risk factors for mental health problems during the COVID-19 epidemic, especially as social restrictions cause pregnant women to be unable to attend prenatal care regularly due to the fear of infection, as the measures to reduce the spread of the virus and the social and familial support from relatives and friends cause the virus to be weakened, as they increase financial difficulties due to economic difficulties and also increase the risk of intimate partner and domestic violence due to increased time spent in closed environments and as a result 
leading to increased anxiety and psychological problems. ${ }^{19}$ Furthermore, because of the possible direct and indirect impact of COVID-19 on perinatal mental wellbeing, it is advised that any pregnant woman receive comprehensive mental health advice and support at every prenatal and postnatal visit. ${ }^{19}$

As a result of the COVID-19 pandemic, 3,166 papers from the quarantine era were reviewed electronically all over the world, and 24 of them were analysed as reviews. Most of the studies reviewed reported negative psychological effects such as post-traumatic stress symptoms, confusion, anxiety, anger, and anger attacks. Longer quarantine periods, fears of infection, disappointment, boredom, insufficient supply, insufficient knowledge, financial loss, and social isolation are all factors that contribute to increased stress. In situations where quarantine is considered essential, it was recommended that experts take adequate quarantine steps for the society, that accurate details regarding a specific justification and protocols for quarantine be given to the public, and that sufficient material and moral equipment be provided. Furthermore, it was claimed that demonstrating the advantages of quarantine to the whole society and illustrating the requisite sacrifice is the most effective method for eradicating the infection as quickly as possible, and therefore the long-term social and psychological consequences of fear and anxiety can be minimized in the most effective way possible. ${ }^{20}$

The limitations of our study include filling out an international questionnaire that is adapted to the entire population in a limited time frame and making it in a limited time frame due to the pandemic.

\section{CONCLUSION}

As a result, the COVID-19 pandemic has a negative impact on the community's mental health, and pregnant women's worries about pregnancy, childbirth, puerperium, and their babies, as well as these social anxiety causes, contribute to a rise in anxiety. Therefore, we believe that adequate psychological and social support for pregnant women and their families should be provided during this period.

Funding: No funding sources

Conflict of interest: None declared

Ethical approval: The study was approved by the Institutional Ethics Committee

\section{REFERENCES}

1. Bouey J. From SARS to 2019-Coronavirus (nCoV): U.S.China Collaborations on Pandemic Response: Addendum. Santa Monica, CA: RAND Corporation. 2020. Available at: https: //www.rand.org/ pubs/testimonies/CT523z2.html. Accessed on 12 May 2021.

2. Yang Y, Peng F, Wang R, Guan K, Jiang T, Xu G, Chang C. The deadly coronaviruses: The 2003 SARS pandemic and the 2020 novel coronavirus epidemic in China. J Autoimmun. 2020;102434.

3. Pfefferbaum B, North CS. Mental Health and the Covid-19 Pandemic. N Engl J Med. 2020;383(6):5102.

4. Schwartz DA, Graham AL. Potential maternal and infant outcomes from coronavirus 2019- NCOV (SARS-CoV-2) infecting pregnant women: Lessons from SARS, MERS, and other human coronavirus infections. Viruses. 2020;12(2):194.

5. Xiang YT, Yang Y, Li W, Zhang L, Zhang Q, Cheung $\mathrm{T}, \mathrm{Ng} \mathrm{CH}$. Timely mental health care for the 2019 novel coronavirus outbreak is urgently needed. Lancet Psychiatry. 2020;7(3):228-9.

6. Ulusoy M, Şahin N, Erkmen H. Turkish version of the Beck anxiety inventory: Psychometric properties. J Cogn Psychotherapy. 1998;12:163-72.

7. Dennis CL, Falah-Hassani K, Shiri R. Prevalence of antenatal and postnatal anxiety: Systematic review and meta-analysis. Br J Psychiatry. 2017;210:315-23.

8. Özdin S, Bayrak Özdin Ş. Levels and predictors of anxiety, depression and health anxiety during COVID-19 pandemic in Turkish society: The importance of gender. Int $\mathrm{J}$ Soc Psychiatry. 2020;66(5):504-11.

9. Verbeek T, Arjadi R, Vendrik JJ, Burger H, Berger MY. Anxiety and depression during pregnancy in Central America: a cross-sectional study among pregnant women in the developing country Nicaragua. BMC Psychiatry. 2015;15:292.

10. Wang C, Pan R, Wan X, Tan Y, Xu L, Ho CS, Ho RC. Immediate Psychological Responses and Associated Factors during the Initial Stage of the 2019 Coronavirus Disease (COVID-19) Epidemic among the General Population in China. Int $\mathrm{J}$ Environ Res Public Health. 2020;17(5):1729.

11. World Health Organization. Global and regional estimates of violence against women: Prevalence and health effects of intimate partner violence and nonpartner sexual violence.2013. Available at: http://apps.who.int/iris/bitstream/10665/85239/1/9789241564625. Accessed on 25 April 2020.

12. Vahratian A, Blumberg SJ, Terlizzi EP, Schiller JS. Symptoms of Anxiety or Depressive Disorder and Use of Mental Health Care Among Adults During the COVID-19 Pandemic - United States, August 2020February 2021. MMWR Morb Mortal Wkly Rep. 2021;70:490-4.

13. Dagklis T, Tsakiridis I, Mamopoulos A, Athanasiadis A, Papazisis G. Anxiety during pregnancy in the era of the COVID-19 pandemic. Available at: https://ssrn.com/abstract=3588542). Accessed on 25 April 2020.

14. Bavel JJV, Baicker K, Boggio PS, Capraro V, Cichocka A, Cikara M, et al. Using social and behavioural science to support COVID-19 pandemic response. Nat Hum Behav. 2020;4(5):460-71.

15. Knight M, Bunch K, Vousden N, Morris E, Simpson N, Gale C, et al. UK Obstetric Surveillance System 
SARS-CoV-2 Infection in Pregnancy Collaborative Group. Characteristics and outcomes of pregnant women admitted to hospital with confirmed SARSCoV-2 infection in UK: national population-based cohort study. BMJ. 2020;369:2107.

16. Poon LC, Yang H, Kapur A, Melamed N, Dao B, Divakar $\mathrm{H}$, et al. Global interim guidance on coronavirus disease 2019 (COVID-19) during pregnancy and puerperium from FIGO and allied partners: Information for healthcare professionals. Int J Gynaecol Obstet. 2020;149(3):273-86.

17. Huizink AC, Mulder EJ, Buitelaar JK. Prenatal stress and risk for psychopathology: specific effects or induction of general susceptibility? Psychol Bull. 2004;130(1):115-42.

18. Lebel C, MacKinnon A, Bagshawe M, TomfohrMadsen L, Giesbrecht G. Elevated depression and anxiety symptoms among pregnant individuals during the COVID-19 pandemic. J Affect Disord. 2020;277:5-13.
19. Coronavirus (COVID-19) infection and pregnancy. Version 13: updated 19 February 2021. Guidance for healthcare professionals on coronavirus (COVID-19) infection in pregnancy, published by the RCOG, Royal College of Midwives, Royal College of Paediatrics and Child Health, Public Health England and Public Health Scotland. Available at: https://www.rcog.org.uk/coronavirus-pregnancy. Accessed on 25 April 2020.

20. Brooks SK, Webster RK, Smith LE, Woodland L, Wessely S, Greenberg N, et al. The psychological impact of quarantine and how to reduce it: rapid review of the evidence. Lancet. 2020;395:912-20.

Cite this article as: Tamburaci E. Anxiety level in pregnant women in the first year of COVID-19 pandemic. Int J Reprod Contracept Obstet Gynecol 2021;10:3670-7. 